\title{
Import Phase-Out Policy of the Travel Industry: Current Implementation Conditions and Regional Specifics
}

\author{
Elena Galenko*, Natalia Ovcharenko, Iuliia Orlovskaia and Daria Romantsova
}

Far Eastern Federal University, School of Economic and Management, FEFU Campus, 10 Ajax Bay,Russky Island, 690922 Vladivostok, Russia

\begin{abstract}
Russia has set a tremendous task to implement import phase-out in the country's travel industry and turn tourism into a competitive, efficient branch of the Russian economy. The implementation of the import phase out policy in tourism takes place in the regions, granting state support, which provides the reducing prices for tourists transport services, forming competitive domestic offers, as well as promoting the existing tourist potential. As a result, the achieved goal of the study allowed us to identify the main conditions necessary for the implementation of the import phase out policy of the travel industry. The hypotheses formed as a result of the study were confirmed. The policy of import substitution of the tourism industry will increase its rating and the level of recognition of its territory, as well as increase the number of domestic and inbound tourist flow, focusing on regional tourist clusters and tourist brands in the region.
\end{abstract}

\section{Introduction}

In recent years, the development of the tourism industry has shown its importance in the profitable businesses structure in the world, where tourism accounted for 7 percent of world trade and employment of every tenth inhabitant of the planet [1]. In 2017, every sixth inhabitant of our planet was a tourist (1.33 billion arrivals), and the total contribution of tourism to world GDP reached $\$ 7.2$ trillion, or $10.2 \%$ [2]. In 2019, the number of international tourists reached 1.5 billion, an increase of 4 percent compared to 2018, which showed a faster growth rate of tourism than the global economy as a whole. It is also necessary to take into account domestic tourism, where the number of tourists reached 8.8 billion people, thereby providing exports of $\$ 1.5$ trillion and employment for many people on the planet [1]. In the context of the national economy impact, the tourism sector, by involving key sectors of the economy (accommodation, transport, communications, construction, agriculture, production of consumer goods, public catering, insurance) in the process of providing tourist services, encourages their development, while increasing production, tax revenues for the treasury, foreign exchange inflows, employment, income of businesses and citizens, and taking measures aimed at restoring and preserving natural resources [3].The tourism sector of Russia, according to the approved by the Tourism

*Corresponding author: galenko_tgey@email.ru 
Development Strategy in the Russian Federation for the period up to 2035, retains significant potential for accelerating growth and strengthening its role in the economy development [4]. However, despite the fact that the tourism industry is a rapidly growing industry that contributes to the socio-economic development of Russia's regions, crises and sanctions not only hinder and restrict its activities, but also force it to look for new development models. In this regard, the study purpose is to determine the main conditions necessary for the regional implementation of the import phase out policy of the tourism industry. The object of the study is tourism of the Primorsky Territory, which occupies a leading position in the development of the hospitality industry among the regions of the Far Eastern Federal District

A set of scientific methods was used in the course of investigations: monographic (when studying tourism as a factor determining regional development); economic-statistical and comparative analysis (when studying trends and patterns of the tourism industry development in the region, determining the key limitations of its development), as well as general scientific research methods.

The findings of the study may help accelerate the tourism recovery in the post-pandemic period for many businesses in the hospitality and tourism industry.

\section{The import phase-out policy of the travel industry}

The Import phase out is a strategy for the domestic economy development, which, due to the imposed external restrictions, remains a technological hub operating with regional resources, recreational space, natural and cultural attractions [5]. Studying the theoretical approaches to the import phase out in the articles of some authors, we can distinguish two vectors of development, structuralist and neo-Keynesian [6]. The structuralist approach is based on the division of the world economy into the center and the periphery. In the 1950s and 1960s, N. Bruton, introduced import substitution as a strategy to promote economic independence and development in developing countries [7]. In the 1970s, import phase out entered the consciousness of the United States as a means of promoting national and regional development. Avik Baza wrote his proposals for the import phase out introduction in the region, based on the study of those industries that occupy a leading position in the local economy. The author described the local economy using the "leaky bucket" model, where the bucket is represented by the local region, and the money is in the form of circulating water inside the bucket, which can be poured and poured into the bucket. Constantly filling the bucket is not the only option: you can also keep more money in circulation in the local economy, blocking the leakage of capital from the system. Import phase out is one of the ways to eliminate these leaks [8].

The foreign experience studied by the authors N. Vatolkina and N. V. Gorbunova allowed us to define three types of import phase out strategy: the strategy of stimulating relatively weak industries, whose products are uncompetitive, in comparison with imported analogues, even in the domestic market; the strategy of creating new industries, the policy of "selfreliance"; the strategy of stimulating developed industries with sufficient potential to expand the export of their products, state support for exports [9].The import phase out policy in various countries is often used not as an alternative, but as an addition to the policy of stimulating exports [10].

As a result, to date, a rich practical experience has been accumulated in the import phase out policies implementation, which some countries consider through the activation of socioeconomic development at the regional and local levels.

In Russia, the import phase out is carried out in many sectors of the real economy and, above all, where there are obvious competitive advantages.

Why has the policy of import phase out in the tourism industry become so relevant right now? 
In the Russian tourism industry, a tremendous task has been set to implement import phase out and turn tourism into a competitive, efficient branch of the Russian economy, a driver of economic growth [11]. In the Russian tourism industry, the import phase out processes began to be considered at the end of the twentieth century and the beginning of the XXI century in connection with the ongoing crises and the introduction of economic sanctions by Western countries. Crises not only threaten the tourism industry, they also have serious consequences for tourists ' choice of destination. Tourists are beginning to react differently to holidays inside or outside the country. For example, the crisis caused by the Ebolavirus in 2014 has greatly affected the West Africa tourism development. An outbreak of SARS (Severe acute respiratory syndrome) in 2003 dramatically reduced tourist demand in East Asia [12]. The sudden outbreak of severe acute respiratory syndrome (SARS) in Singapore in 2003 was a major crisis for the tourism industry as a whole and highlighted the importance of finding new models for effective management and planning [13].

Mid-March of the 2020, was a new report of the tourism industry development in all countries. In the first months of this period, the number of international tourists decreased by 56 percent, increasing to 98 percent by May. The COVID-19 pandemic has had a devastating impact on the world's economy and employment. In Brazil, the tourism industry has reduced hotel services by $80 \%$, all parks and attractions have been closed, and the tourists flow may be reduced by $50 \%$ in 2020 . In France, self-isolation measures have led to the closure of 75,000 restaurants, 3,000 clubs and 40,000 cafes, thereby creating technical unemployment for 2 million workers in the hospitality and tourism industries. $80 \%$ of hotel and restaurant workers were put on holiday in the tourist areas of the United Kingdom. In the United States, about 1.6 million hotel workers have been laid off or put on leave since the crisis began, and 3.9 million hotel-dependent jobs have been lost. [14]. According to the analytical center under the government of the Russian Federation, revenues from the export of tourist services in the world in January-August 2020 decreased by 730 billion US dollars, which is more than 8 times higher than the losses in the crisis of 2009 year. The monitoring of industry financial flows and incoming payments in the Russian tourism industry in May 2020 lagged behind the pre - coronavirus "norm" by $90 \%$, in June — by $80-90 \%$, by the end of July by $66 \%$, by the end of August-by $54 \%$ [15]. The monitoring of the economic situation in Russia revealed that before the pandemic, the tourism share and related industries in GDP was about 5\% (5 trillion 442.9 billion rubles), providing $5.6 \%$ of total employment (more than 4 million people). During the crisis associated with the COVID-19 pandemic: the depth of cancellation of tours in Russia is 3-6 months (50-80\%), in the case of outbound tourism, the reservations cancellation is $100 \%$ with a booking depth of 4-7 months. The revenue of $95 \%$ of the tourism industry companies (most of which are SMEs) fell to zero, and the load on collective accommodation facilities decreased to $0-3 \%$ [16]. These indicators identified the Russian tourism industry as one of the most affected during the pandemic. According to the researchers, the tourist destination ability to respond to sanctions and crises underscores the extent to which lessons have been learned from previous experiences of the pandemic and adapt accordingly. Currently, destinations and enterprises of the tourism and hospitality industry react to what is happening, develop long-term development plans that affect competing destinations [17].

The import phase out policy can be the first step towards the implementation of changes in the economy and the tourism industry improvement. Therefore, the tourism industry import phase out should be developed on the basis of the stimulating the developed sectors strategy of the hospitality and tourism industry that have sufficient potential to expand the export of their products, taking into account the state support for exports. Thus, we put forward the following hypotheses: 
H1

The proposed import phase out policy of the tourism industry by focusing on the tourist brands of the region will increase its rating and the level of the territory recognition.

$\mathrm{H} 2$

The proposed import phase out policy of the tourism industry by focusing on regional tourism clusters will increase the number of domestic and inbound tourist flows.

In this regard, at the first stage of import phase out of the tourism industry, proposed to focus on those regional tourism clusters and brands that are leading in their field of activity, and are in great demand among tourists in domestic and inbound destinations.

\subsection{Current conditions for the implementation of the import phase out policy the tourism industry}

Restructuring and import phase out of the tourism industry, as its integral element, should be based on the relevant state policy, taking into account the strategic plans development of domestic and inbound tourism in the regions.

What conditions, formed with the help of state support, are currently being implemented within the framework of the import phase out policy of the tourism industry?

In the Concept of the Federal Target Program "Development of domestic and inbound tourism in the Russian Federation (2019 - 2025)", domestic tourism is considered as one of the import phase out tasks, and the inbound tourism development is one of the promising ways to solve the problem of increasing the share of non-commodity exports in the total export volume of the country, set by the President of the Russian Federation [18].The approach developed in the concept makes it possible to coordinate and concentrate efforts on supporting investment projects that are significant for the region, creating and modernizing tourist clusters, where there is a high potential for the development of a particular type of priority tourism in a clear link with the existing tourist attraction centers. The "Strategy for the Tourism Development in the Russian Federation for the period up to 2035" was approved, which provides for the comprehensive development and the tourist territories improvement, including the tourist development, municipal and transport infrastructure, construction and reconstruction of main infrastructure facilities, and the tourist product formation taking into account the natural, cultural, and ethnic diversity of Russian regions [4]. Since 2020, as provided for by the Rules for Granting Subsidies from the federal budget for grant support of Public and business initiatives aimed at the development of domestic and inbound tourism, the federal budget has allocated 54 million rubles per year [19]. From September 22 to October 8, 4061 projects were submitted for consideration, 2735 applications were allowed to participate in the competition. The average amount of the requested grant was 2.6 million rubles. The winners were 474 companies that will direct their funds to create comfortable and safe conditions for recreation on the landscape, to develop new tourist routes that contribute to the tourist clusters formation and brands in the regions $[20]$.

Another priority condition for the implementation of the import phase out policy is the state support in the form of stimulating domestic tourist flows. The Russian government has allocated 15 billion rubles for the implementation of the "tourist cashback" program, using the MIR payment system card when paying for a tour. As part of the first stage, from August 21 to August 28, 2020, the allocated funds for paying tourists for trips around Russia amounted to 15 thousand rubles at the sales cost of the tour from 75 thousand rubles. When buying a tour worth from 50 thousand rubles to 74.9 thousand rubles, the refund was 10 thousand rubles from 25 thousand rubles to 49.9 thousand rubles -5 thousand rubles. As part of the first stage, 60 thousand Russian citizens took advantage of the program, spending about 1.4 billion rubles on tours and accommodation [15]. 
As a result, the formed conditions for the implementation of the import phase out policy of the tourism industry require large-scale investments and solutions to the issue of financing sources. In addition to financing from various sources, the import phase out support involves stimulating consumers to develop domestic and inbound tourism. It is also necessary to take into account the different resource opportunities and the level of economic development of the regions. Therefore, the task of each region is to determine the tourist priorities and concentrate all efforts on the selected destinations. Let's turn to the import phase out experience of the tourism industry in the Primorsky Territory - a subject of the Russian Federation, which is part of the Far Eastern Federal District.

\section{The import phase out policy of the tourism industry (using the example of of Primorsky Krai)}

Over the past few years, there has been a steady annual increase in the incoming tourist flow in Primorye. In 2019, the Primorsky Territory received about 70 percent of the tourists who visited the Far East - five million guests, one million of whom are foreign. The tourism industry gave the region more than 5.1 billion rubles in tax deductions, 39 thousand people were employed in this segment. Today, the tourism contribution to the GRP of the region has become much greater, if compared with 2013, when the number of visitors was 1.5 million, and in 2019 more than 5 million people [21].

Primorye has more than 520 unique natural objects (lakes, waterfalls, ancient extinct volcanoes, caves), 6 state nature reserves are located in the region, and national parks are important for the inbound and domestic tourism development

All of these things helps to attract a large number of tourists every year, thereby opening new hotels and other accommodation facilities. The growth in the number of enterprises in the Primorsky Territory is leading in comparison with other regions of the Far Eastern Federal District (Fig. 1.).

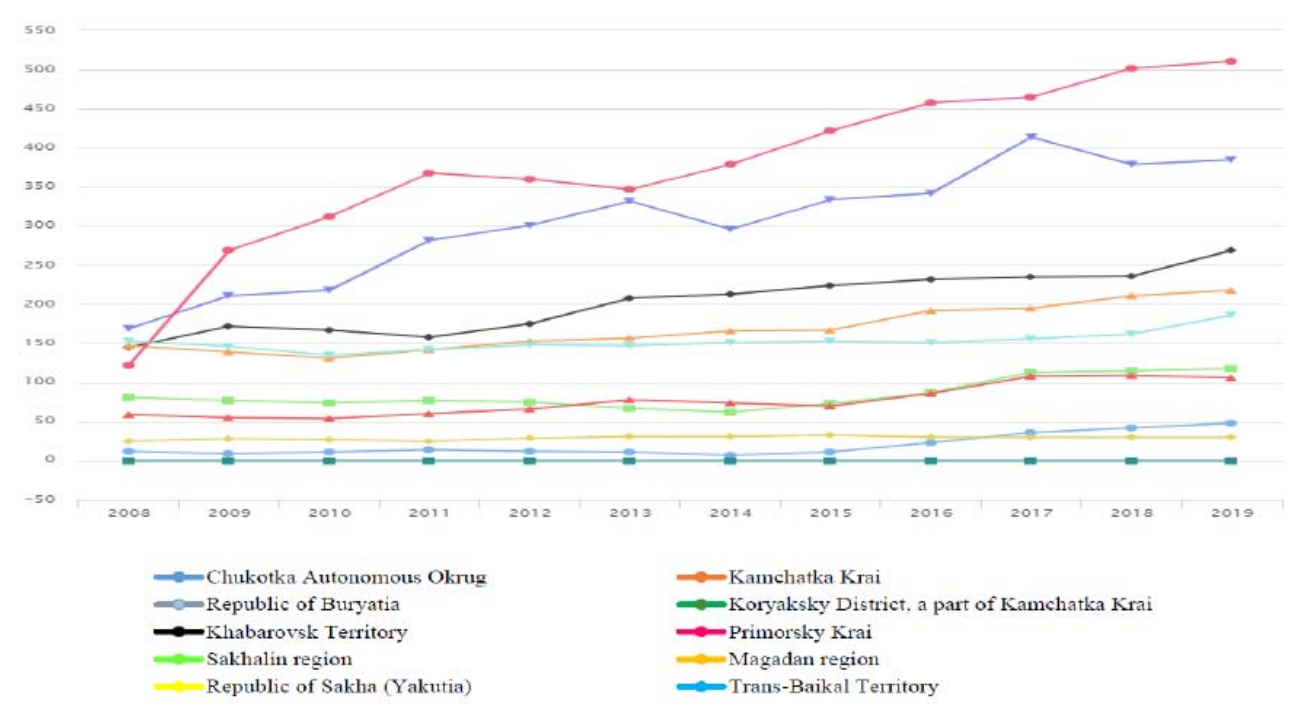

Source: https://fedstat.ru

Fig. 1. Number of the collective accommodation facilities from 2008 to 2019.

The development of hotels and other accommodation facilities in 2019 reached 511 enterprises. At present time, at the level of the Primorsky Territory regional authorities, new 
tourist brands are being developed. Every year, there is a search for new destinations, some brands have become winners of the "National Rating of Travel Brands 2018", presented in Table 1.

Table 1. Brands of Primorsky Krai

\begin{tabular}{|c|c|c|}
\hline Place & Brand Name & Total number of points \\
\hline \multicolumn{3}{|c|}{ Category «Hotels and inns» } \\
\hline 1 & Hotel complex "Warm Sea" (Primorsky Krai) & 30,3 \\
\hline \multicolumn{3}{|c|}{ Nomination «Amusement Park» } \\
\hline 3 & Primorsky Safari Park (Primorsky Krai) & 22,3 \\
\hline \multicolumn{3}{|c|}{ Nomination «Aquarium» } \\
\hline 2 & Primorsky oceanarium (Vladivostok) & 34,8 \\
\hline \multicolumn{3}{|c|}{ Nomination «Regional event» } \\
\hline 2 & Pacific Tourism Forum (Vladivostok) & 22 \\
\hline
\end{tabular}

Source: https://rustur.ru/

The tourists attractiveness for the new tourist objects, cultural objects, transport and tourist infrastructure of the Primorsky Krai brands created in the region has allowed to increase the level of recognition of the Primorsky Krai territory, which was confirmed by the data for five years of the National Tourist Rating presented in Table 2.

Table 2. National Tourist Rating of Primorsky Krai (2015-2019)

\begin{tabular}{|c|c|c|}
\hline $\begin{array}{l}\text { Rating } \\
\text { place }\end{array}$ & Name of the Russian Federation subject of & Total score \\
\hline \multicolumn{3}{|c|}{$\begin{array}{l}\text { the first group of the } 2015 \text { rating includes regions that have passed the } 50 \text {-point threshold: from } 1 \\
\text { to } 16 \text { places inclusive }\end{array}$} \\
\hline 14 & Primorsky Krai & 51 \\
\hline \multicolumn{3}{|c|}{$\begin{array}{l}\text { the first group of the } 2016 \text { rating includes regions that have passed the } 60 \text {-point threshold: from 1st } \\
\text { to } 21 \text { st place inclusive }\end{array}$} \\
\hline 10 & Primorsky Krai & 65 \\
\hline \multicolumn{3}{|c|}{ The first group of the 2017 rating (TOP 20) includes regions from 1st to 20th place inclusive. } \\
\hline 9 & Primorsky Krai & 83,7 \\
\hline \multicolumn{3}{|c|}{$\begin{array}{c}\text { the first group of the } 2018 \text { rating - the "Golden Twenty" - includes regions from 1st to 20th place } \\
\text { inclusive }\end{array}$} \\
\hline 8 & Primorsky Krai & 92,1 \\
\hline \multicolumn{3}{|c|}{$\begin{array}{c}\text { the first group of the } 2019 \text { rating - the "golden twenty" - includes regions from 1st to 20th place } \\
\text { inclusive }\end{array}$} \\
\hline 7 & Primorsky Krai & 101,8 \\
\hline
\end{tabular}

Source: https://rustur.ru/

There are hotels, campsites, recreation centers and sanatoriums, as well as interesting tourist sites: tourist and recreational clusters "Primorsky Ring", "Warm Sea" and "Emerald Ring", the Primorsky Oceanarium, the Primorsky stage of the Mariinsky Theater and much more. The model of the "leaky bucket" of the Primorsky Territory is annually replenished due to income from visits by tourists to the annual Eastern Economic Forum, the gambling zone "Primorye", the hospitality industry enterprises, the active development of cruise, gastronomic and other types of tourism, electronic visas for incoming tourists, which allows the region to develop not only tourism, but also the entire economy at a more dynamic pace (Figure 2). 


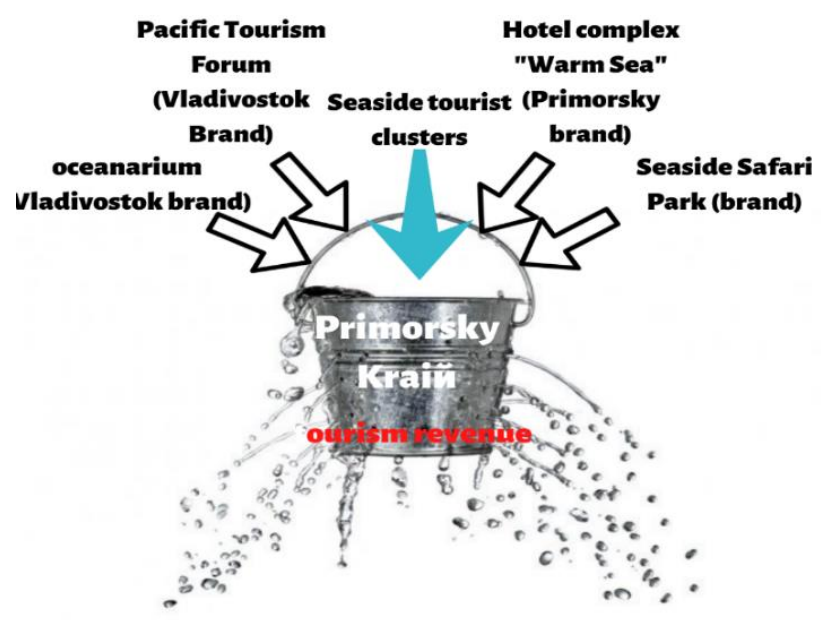

Source: compiled by the authors

Fig. 2. The model of the "leaky bucket" of the Primorsky Krai.

Nevertheless, the water leakage can be eliminated if the import phase out policy of the tourism industry is applied, involving the local population in order to tourism develop. Residents of Primorsky Krai should see the benefits of visiting tourists, then the emergence of new jobs, a positive impact on the residents hospitality of Primorye, it will affect the tourist attractiveness of Primorsky Krai.

\section{Discussion}

The relevance of the import phase out policy in the tourism industry today is due to the COVID-19 pandemic, which has had a devastating impact on the economy and employment not only in the Russia regions, but also in the world as a whole. The Russian Federation Government has developed programs and strategies, which consider in detail the Set of tasks for the organization of tourist products import phase out, the Government Committee on Import Substitution and the Coordinating Council for the Development of Domestic and Inbound Tourism in the Russian Federation have been established at the federal level. The studied theoretical material allowed us to conclude that the implementation of the import phase out policy in the tourism industry is primarily aimed at the development of domestic and inbound tourism, and the formation of conditions for "growth points" in the form of tourist clusters and brands that can compete not only in the domestic tourism market. In Primorsky Krai, tourism develops on a cluster approach, which involves the association of tourism business entities, representatives of local authorities, scientific and educational institutions, the public and enterprises of related industries, and tourist brands that contribute to the creation, development and strengthening of the region image in the tourist market. The "leaky bucket" model clearly shows how tourist brands and clusters in the region focus on ensuring that money flows continuously to the local budget, most of it remaining in the form of local development revenues, increasing the level of the territory recognition and increasing the number of domestic and inbound tourist flows, which confirms the formulated hypotheses. 
We thank the administration for providing data of the tourism industry development in the region and the respondents for their useful comments.

\section{References}

1. Analytical note: COVID-19 and the restructuring of the tourism sector. United Nations - August, 29 (2020)

2. N. A. Zyulyaev, Analysis of mutual tourist flows between Russia and the EU countries. Service in Russia and abroad, 3, 85, (2019)

3. E. G. Leonidova, Tourism problems as a factor of regional development in the context of the Covid-19 pandemic impact. Actual Problems of Economics and Law 14, 3 (2020)

4. Strategy for the Development of tourism in Russia until 2035: Decree of the Russian Federation Government No. 2129-r of September 20, 2019.

5. T. V. Uskova, V. K. Egorov, E. G. Leonidova, Tourism in the Russian Federation: opportunities for import phase out. The territory development problems. 4,84 (2016)

6. Y. Simachev, M. Kuzyk, N. Zudin, Import Dependence and Its Substitution in the Russian Manufacturing. Business Viewpoint. Foresight and STI Governance, 10, 4, (2016)

7. H. Bruton, A Reconsideration of Import Substitution. Journal of Economic Literature. 36, 2 (1998)

8. Avik Basu, Import substitution as economic development (2005)

9. N. Vatolkina, N. V. Gorbunova, Import phase out: international experience, tools. Bulletin of Economics, 233,6 (2016)

10. A.A. Gnidchenko, Import substitution as a complementary strategy. Stud. Russ. Econ. Dev., 28 (2017).

11. N. M. Mukhetdinova, Import phase out in the Russian tourism industry. Finance: theory and practice. 2,92 (2016)

12. L. Senbeto \& Dagnachew, H. Y. Hon Alice, The impacts of social and economic crises on tourist behaviour and expenditure: an evolutionary approach, Current Issues in Tourism, 23,6 (2020)

13. Susana Cró, António Miguel Martins, Structural breaks in international tourism demand: Are theycaused by crises or disasters? Tourism Management, 63 (2017).

14. ILO Industry Reference: COVID-19 and the tourism sector. International Labour Organization, 11 (2020)

15. Bulletin on current trends in the Russian economy. Dynamics of demand for tourist services in Russia against the background of the COVID-19 pandemic. Analytical Center under the Government of the Russian Federation. Issue 68 (2020)

16. Monitoring of the economic situation in Russia. Trends and challenges of socioeconomic development. 17, 119 (2020)

17. C. Michael Hall, Daniel Scott \& Stefan Gössling Pandemics, transformations and tourism: be careful what you wish for, Tourism Geographies, 22, 3, (2020)

18. Concept of the Federal target program " Development of Domestic and Inbound Tourism in the Russian Federation (2019-2025)" (as amended on July 11, 2019): Order of the Russian Federation Government No. 872-r of May 5, 2018

19. Rules for granting subsidies from the federal budget for public grant support and business initiatives aimed at the development of domestic and inbound tourism: Order of the Russian Federation Government No. 1619 of December 7, 2019

20. 474 projects in the field of tourism have been identified, which will receive grants from the Federal Tourism Agency on November 12, 2020 https://tourism.interfax.ru

21. Tourist business expects to make money on the growing foreign flow in Primorye Vestnik ATOR 06.11.2019 